\title{
Modeling and assessing land-use and hydrological processes to future land-use and climate change scenarios in watershed land-use planning
}

\author{
Yu-Pin Lin · Nien-Ming Hong $\cdot$ Pei-Jung Wu • \\ Chien-Ju Lin
}

Received: 15 September 2006/ Accepted: 5 February 2007/Published online: 1 March 2007

(C) Springer-Verlag 2007

\begin{abstract}
Effective information regarding environmental responses to future land-use and climate change scenarios provides useful support for decision making in land use planning, management and policies. This study developed an approach for modeling and examining the impacts of future land-use and climate change scenarios on streamflow, surface runoff and groundwater discharge using an empirical land-use change model, a watershed hydrological model based on various land use policies and climate change scenarios in an urbanizing watershed in Taiwan. The results of the study indicated that various demand and conversion policies had different levels of impact on hydrological components in all land-use scenarios in the study watershed. Climate changes were projected to have a greater impact in increasing surface runoff and reducing groundwater discharge than are land use changes. Additionally, the spatial distributions of landuse changes also influenced hydrological processes in both downstream and upstream areas, particularly in the downstream watershed. The impacts on hydrological components when considering both land use and climate changes exceeded those when only considering land use changes or climate changes, particularly on surface runoff and groundwater discharge. However,
\end{abstract}

\section{Y.-P. Lin $(\bowtie) \cdot$ P.-J. Wu · C.-J. Lin}

Department of Bioenvironmental Systems Engineering,

National Taiwan University, 1 Section 4 Roosevelt Road,

Taipei 10617, Taiwan

e-mail: yplin@ntu.edu.tw

\section{N.-M. Hong}

Department of Environmental Resources Management,

The Overseas Chinese Institute of Technology,

Taichung, Taiwan the proposed approach provided a useful source of information for assessing the responses of land use and hydrological processes to future land use and climate changes.

Keywords Impact assessment - Land-use modeling · Hydrological modeling · Climate change $\cdot$ Hydrological components · Land-use planning policy · Taiwan

\section{Introduction}

Conversion of land-use to feed and shelter increased human enterprises has been one of the major modes for human modification of the global environment (DeFries and Eshleman 2004), and of the local environment such as hydrological processes. Land-use changes can influence hydrological processes including infiltration, groundwater recharge, base flow and runoff in a watershed. For example, watershed development reduces base flow by changing groundwater flow pathways to surface-water bodies. Global warming resulting from increases in atmospheric greenhouse gasses will alter global weather patterns and affect the hydrologic cycle (Thomson et al. 2005). The capacity of the atmosphere to hold water will increase, leading to more precipitation and evaporation globally (Thomson et al. 2005). Changes in global climate will have significant impact on local and regional hydrological regimes, which will in turn affect ecological, social and economical systems (Dibike and Coulibaly 2005). Therefore, modeling and understanding responses of land use compositions and hydrologic components to both future land use and climate change scenarios is useful for optimizing land use planning, 
management and policy in a watershed, particularly an urbanizing watershed.

Comprehensive knowledge of land use dynamics is useful for reconstructing past land-use/land cover changes and for predicting future changes, and thus may help in elaborating sustainable management practices aimed at preserving essential landscape functions (Hietel et al. 2004). Several models have been developed for examining land-use change. Recent examples of land-use models include stochastic models (Weaver and Perera 2004), optimization models (Wang et al. 2004; Manson 2005), cellular automata (Syphard et al. 2005; Bolliger 2005), agent-based models (Evans and Kelley 2004; Manson 2005) and empirical models (Aspinall 2004; Verburg and Veldkamp 2004; Agarwal et al. 2005; Fang et al. 2005). However, land use change is frequently studied through a process of empirical modeling of documented changes in land cover or land use patterns (Aspinall 2004). Empirical models provide a mechanism for analyzing detailed case studies and can help identify the key drivers of land cover and land use changes (Turner et al. 1993; Aspinall 2004).

In climate change studies, the widely used methods for generating climate change scenarios are general circulation models (GCMs), which represent the most sophisticated attempt to date to simulate climate on a global scale. These models currently offer the most credible methods of simulating global climate responses to increased greenhouse gas concentrations, and provide estimates of climate variables (Prudhomme et al. 2003). GCMs are computerized, threedimensional, mathematical representations of the Earth's atmosphere and are based on fundamental laws governing atmospheric physics (Ringius et al. 1996; Matondo et al. 2004). GCMs calculate wind speed, temperature, and atmospheric moisture distribution as well as surface climate/weather variables. However, GCMs are used to perform two types of simulation experiments for estimating future climates, namely equilibrium and transient experiments. Most calculations use the equilibrium mode, in which the models are subjected to an instantaneous effective doubling of $\mathrm{CO}_{2}$ concentrations relative to a base year, and are then run to simulate an equilibrium climate under those hypothetical conditions (Matondo et al. 2004).

A watershed hydrology model comprises a set of mathematical descriptions of portions of the hydrologic cycle (Singh and Woolhiser 2002). Recently, hydrological simulation models have been widely used to quantify the influence of land use change on the hydrologic cycle. Hydrological watershed models can be used to simulate streamflow, runoff, groundwater discharge, sediment, and nutrient loadings in watersheds given variable sized source areas, different landuse and climate scenarios assessing the impacts of landuse and climate changes in a watershed. Therefore, hydrological models offer a useful means of evaluating the effect of changes in landscape patterns or land use resulting from policy decisions, economic incentives or structural economic changes (Fohrer et al. 1999, 2002, 2005), and even the impacts of climate change on the hydrological cycle.

The first step in this study is to simulate future land-use scenarios by using the conversion of land use and its effects model (CLUE-S) based on logistic regression models, with the driving factors including spatial and non-spatial policies and land-use demands, for the Wu-Tu watershed in Taiwan (Fig. 1).

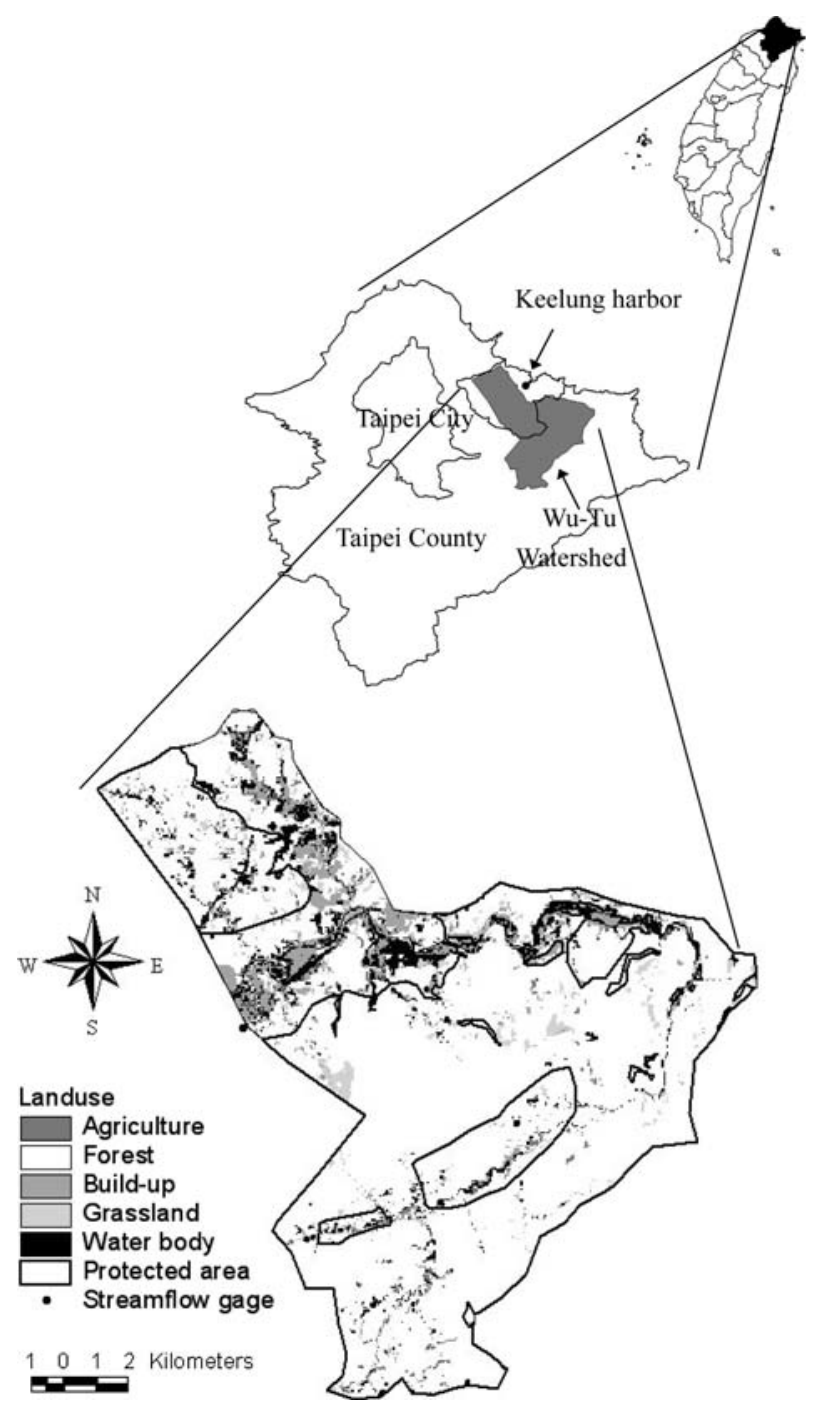

Fig. 1 Study watershed 
Following land use simulations, the generalized watershed loading functions (GWLF) model simulates annual streamflow, runoff and groundwater discharge in land use scenarios and climate change scenarios for both the entire watershed and the upstream watershed of the study area. The climate change scenarios are generated from the GCMs models. This study then discusses the above hydrological components for the hypotheses that future land-use and climate changes impact surface runoff, groundwater discharge and streamflow in the study watershed.

\section{Materials and methods}

\section{Study area}

The $\mathrm{Wu}-\mathrm{Tu}$ watershed is an urbanizing watershed in the Keelung River Basin, located between the Taipei metropolitan area and Keelung Harbor in northern Taiwan (Fig. 1). The Wu-Tu watershed has an area of approximately $204.41 \mathrm{~km}^{2}$, with a mean elevation and mean slope of $242.00 \mathrm{~m}$ and $0.005^{\circ}$, respectively. The population in this watershed increased owing to the expansion of the Taipei metropolitan area, Keeling city and the need for labor of Keelung Harbor during 19871997. Driven by population growth, the watershed has become a rapidly urbanizing watershed with an average annual population increase of approximately $2.70 \%$ during 1987-1997, especially in the downstream area of the watershed (Cheng and Wang 2002). Since 1997, the average annual population growth rate has been approximately $1.05 \%$ (Cheng and Wang 2002).

\section{Land-use change model}

In the CLUE-S model, the non-spatial module calculates the area of change for all land-use types at the aggregate level, and the spatial module in the CLUE-S translates demands into land-use changes at various locations within the study region (Verburg et al. 2002). The relationships between land use and its drivers can be fitted by using the stepwise logistic regression. Furthermore, probability maps for all land-use types can be established using logistic regression models. The explicit spatial allocation procedure converts non-spatial demands into land-use changes at various locations in the study area. The relationships between land uses and its drivers were evaluated by following stepwise logistic regression (Verburg et al. 2002): $\log \left(\frac{P_{i}}{1-P_{i}}\right)=\beta_{0}+\beta_{1} X_{1, i}+\beta_{2} X_{2, i}+\cdots+\beta_{n} X_{n, i}$

where $P_{i}$ denotes the probability of a grid cell for the occurrence of the considered land use type, the $X_{s}$ are driving factors and $\beta_{i}$ is the coefficient of each driving factor in the logistic model.

After fitting the logistic regression models for all land use types, the restricted area and land use transition rules were specified for the study watershed. Finally, land-use change is allocated in the following iterative procedure according to probability maps, the decision rules combined with the actual land-use maps, and the demand for different land uses (Verburg et al. 2002). For each grid cell the total probability is calculated for each of the land use types based on the logistic model results with land use change priority and the iteration variable.

The first step of the iterative procedure makes a preliminary allocation for which the iteration variable has an equal value for all land use types by allocating the land use type with the highest total probability of land use occurrence for the considered grid cell (Verburg et al. 2002). Conversions that are not permitted in the conversion matrix are not allocated. The total allocated area of each land use is then compared to the land use demand. For land use types where the allocated area is smaller than the demanded area the value of the iteration variable is increased. Meanwhile, for land use types with too much allocation the value of the iterative variable is reduced. The above procedures are repeated as long as the demands are not correctly allocated. When allocation and demand are equal the final land use at this time step is saved and the allocation procedure continues for the next yearly time step until reaching the target year. Furthermore, the grid cells located in the restricted area are not allowed to convert into other land use types during the allocation.

\section{Hydrological model}

The generalized watershed loading functions model developed by Haith and Shoemaker (1987) is a combined distributed/lumped parameter watershed model for simulating runoff, sediment, and nutrient loadings in watersheds given variable sized source areas (such as agricultural, forested, and developed land). Surface loading is distributed in the sense that multiple land 
use and land cover scenarios are permitted where each area is assumed to have homogeneous attributes when addressed by the model (Haith and Shoemaker 1987). For subsurface loading, the model is a lumped parameter model utilizing a water-balance approach. Daily water balances are calculated for unsaturated and saturated sub-surface zones, in which infiltration is calculated as the difference between precipitation and snowmelt minus surface runoff plus evapotranspiration (Haith and Shoemaker 1987).

In the GWLF model, the water mass balance equation for the unsaturated zone (Howarth et al. 1991; Tung 2001) can be represented by:

$U_{t+1}=U_{t}+I_{t}-\mathrm{ET}_{t}-\mathrm{PC}_{t}$

where $U_{t+1}(\mathrm{~cm})$ and $U_{t}(\mathrm{~cm})$ are the moisture contents of the root zone in excess of the field capacities on days $t+1$ and $t$, respectively, $I_{t}$ denotes the infiltration $(\mathrm{cm})$, $\mathrm{ET}_{t}$ represents the evapotranspiration $(\mathrm{cm})$ during day $t$, and $\mathrm{PC}_{t}$ is the percolation $(\mathrm{cm})$ into the deep saturated zone on day $t$.

The difference in infiltration between rainfall $\left(R_{t}\right)$ and surface runoff $\left(Q_{t}\right)$, can be calculated by

$I_{t}=R_{t}-Q_{t}$

Evapotranspiration is influenced by atmospheric conditions and use and soil moisture content, which have the following relationship (Tung 2001):

$\mathrm{ET}_{t}=\operatorname{Min}\left[k_{\mathrm{st}} \times k_{\mathrm{ct}} \times \mathrm{PET}_{t}, U_{t}+I_{t}\right]$

where $k_{\mathrm{st}}$ and $k_{\mathrm{ct}}$ are the coefficients of soil moisture stress and land cover, respectively, and $\mathrm{PET}_{t}$ is the potential evapotranspiration calculated using the Hamon equation (Hamon 1961; Tung 2001):

$\mathrm{PET}_{t}=\left(0.021 D_{t}^{2}\right)\left(e_{\mathrm{st}}\right) / T_{t}$

where $D_{t}$ is the number of daylight hours on day $t, e_{\mathrm{st}}$ is the saturated water vapor pressure on day $t$, and $T_{t}$ is the absolute temperature on day $t$. Land cover coefficients of agricultural land, forest, build-up area, grassland, and water body are 1, 1, 0.2, 0.83-1.25, and 1, respectively. Moreover, percolation occurs when soil moisture of an unsaturated zone exceeds field capacity, and is calculated by

$\mathrm{PC}_{t}=\max \left[0, U_{t}+I_{t}-\mathrm{ET}_{t}-U^{*}\right]$

where $U^{*}$ denotes the maximum soil water capacity $(\mathrm{cm})$.

The water balance equation for the shallow saturated zone is:
$S_{t+1}=S_{t}+\mathrm{PC}_{t}-G_{t}-D_{t}$

where $S_{t}(\mathrm{~cm})$ denotes the water content of a shallow ground water aquifer at the beginning of day $t, D_{t}$ represents the deep seepage $(\mathrm{cm})$ during day $t$ and $G_{t}$ $(\mathrm{cm})$ is groundwater discharge to streams/rivers.

The movement of water from the saturated zone to streams/rivers $\left(G_{t}\right)$ is considered to be a linear function of the moisture content of the saturated zone (Howarth et al. 1991; Tung 2001), and can be calculated using the following equation.

$G_{t}=r S_{t}$

where $r$ is the recession coefficient.

This study uses 10-year (1993-2002) streamflow data to verify the simulated streamflow modeled with the GWLF model using historical weather data and parameters that include the recession coefficient, evapotranspiration coefficient and the curve number for the study watershed. The linear regression of mean monthly observed streamflows and mean monthlysimulated streamflows is performed for verifying hydrological model parameters. However, a perfect fit of a linear regression has a regression slope (regression coefficient) of 1.0. Model parameters are set when a perfect fit of a linear regression of mean monthly observed streamflows and mean monthly simulated streamflows is reached. In this study, $R^{2}$ value of the linear regression model with slope of 1.0 (regression coefficient) of the monthly mean observed streamflows and the mean monthly simulated streamflows during the 10 -year period is 0.98 . The linear regression model is significant at the 0.01 level. The mean error of the mean monthly simulated streamflows is $0.72 \mathrm{~cm}$. The verification analysis indicates that the hydrological model perfectly simulates mean monthly streamflows.

Land-use demand and conversion policies

The proposed restricted areas are intended to protect hillsides, water supply sources and large forested areas as part of a conservation policy (Fig. 1). To further simulate land use, data are required for the land use distribution and the number of biophysical and socioeconomic parameters considered as potential drivers of land use patterns, namely altitude $(\mathrm{m})$, slope, distance to river, soil erosion coefficient, soil drainage, distance to major road, distance to built up area, distance to urban planning area and population density. This study obtained land use data 1999 from the Soil and Water Conservation Bureau of the Council of Agriculture, Taiwan. Land use maps, which were generated and 
digitized by the Soil and Water Conservation Bureau using 1:5,000 aerial photographs taken in 1999, distinguishes among 33 land-use types in a vector format. According to the definitions of land-use types produced by the Construction and Planning Agency of the Ministry of Interior, Taiwan, this study converted the above 33 land-use types to be five land-use types, including agricultural land, forest, built-up area, grassland, and water body, and classified land-use using a $50 \times 50 \mathrm{~m}$ resolution based on these types. The proportions of agricultural land, forest, built-up area, grassland, and water body in 1999 were 1, 83, 6, 3 and $7 \%$, respectively. This study used the logistic regression model developed by Lin et al. (2007), listed in Table 1.

Two land-use demands (namely low and high development demand), based on annual birth rates of 1.17 and $1.50 \%$, are used as input data to further simulate land-use scenarios from 2000 to 2020. Furthermore, the water body was assumed to be constant for both land-use demands during the period 20002020. For each land-use type, conversion rules determine the conditions under which land-use changes in the next time step. The 1995 agricultural land release policy of the Council of Agriculture, Executive Yuan, Taiwan, involves two land-use conversion rules (free conversion and agricultural protection conversion) based on the regulations and the agricultural land release policy. The free conversion specifies that agricultural, forest and grasslands can be converted into any of these three land uses, while built-up area and water bodies cannot be converted into other land uses.

Table 1 Logistics regression model for land use types

\begin{tabular}{lcclc}
\hline Variable & Agriculture & Forest & Build-up & Grass \\
\hline Dtm & 0.0015 & 0.0016 & - & -0.0043 \\
Slope & -0.041 & 0.0653 & -0.0203 & -0.0278 \\
Popd & 0.0002 & -0.0001 & $3.17 \mathrm{E}-05$ & - \\
Droad & -0.0012 & -0.0002 & - & 0.0011 \\
Driver & - & 0.0001 & - & -0.0002 \\
Dbuild & -0.0019 & 0.0069 & -0.0627 & -0.0025 \\
Dzone & 0.0003 & - & - & $-9.34 \mathrm{E}-05$ \\
Odr & - & - & - & 0.467 \\
Soilk & 2.1461 & 4.6479 & -1.8691 & - \\
Constant & -3.1464 & -1.4859 & 1.5537 & -2.3934 \\
ROC & 0.735 & 0.88 & 0.983 & 0.757 \\
\hline
\end{tabular}

Dtm altitude, Slope slope; Popd population density, Droad distance to major road, Driver distance to river, Dbuild distance to buildup area, Dzone distance to urban planning area, $O d r$ soil drainage, Soilk soil erosion coefficient

- Not significant and not included in model at 0.05 significant level
The agricultural protection conversion does not allow agricultural land to be converted into built-up area and forest. The main difference between conversions is that agricultural land cannot be converted into built-up area in the agricultural protection conversion. Based on land-use demand and conversion rules, scenarios I (low development demand and free conversion), II (high development demand and free conversion), III (high development demand and agricultural protection conversion) and IV (low development demand and agricultural protection conversion) are simulated in the study area.

\section{Climate change scenarios}

This study used rainfall and precipitation data from three GCMs (general circulation models) simulations, namely CGCM1, HadCM2 and GFDL-R15, representing three modeling centers, namely the Canadian Centre for Climate Modeling and Analysis, the Hadley Centre for Climate Prediction and Research, and the USA Geophysical Fluid Dynamics Laboratory. The future temperature change in the study area is assumed to be the same as the difference between the temperatures simulated using GCMs for the future and current conditions at the nearest grid point (Tung et al. 2005). Consequently, future climate scenarios can be estimated as follows (Tung et al. 2005)

$\mu_{\mathrm{mT}}^{\prime}=\mu_{\mathrm{mT}}+\left(\mu_{\mathrm{mT}, \text { future }}-\mu_{\mathrm{mT}, \text { current }}\right)$

where $\mu_{\mathrm{mT}}$ and $\mu_{\mathrm{mT}}^{\prime}$ denote current and future mean monthly temperature $\left({ }^{\circ} \mathrm{C}\right)$, respectively, and $\mu_{\mathrm{mT} \text {,current }}$ and $\mu_{\mathrm{mT} \text {,future }}$ represent simulated mean monthly temperatures $\left({ }^{\circ} \mathrm{C}\right)$ under the current and future climate conditions, respectively. The change in precipitation is assumed to be the ratio of the precipitation for the future condition to that for the current condition (Tung et al. 2005):

$\mu_{\mathrm{mP}}=\mu_{\mathrm{mP}}+\left(\mu_{\mathrm{mP}, \text { future }}-\mu_{\mathrm{mP}, \text { current }}\right)$

where $\mu_{\mathrm{mP}}$ and $\mu_{\mathrm{mP}}^{\prime}$ are current and future mean monthly precipitation $(\mathrm{cm})$, respectively, while $\mu_{\mathrm{mP} \text {,current }}$ and $\mu_{\mathrm{mP} \text {,future }}$ are simulated mean monthly precipitation $(\mathrm{cm})$ under the current and future climate conditions, respectively. The predictions of the GCM equilibrium experiments (1995 version) are downloaded from the US Country Studies Program (1995), which is available on the web at the NCAR ftp site (ftp://www.ncardata.ucar.edu/pub). Table 2 lists the changes in temperature and precipitation ratios. 
Table 2 The changes in temperature and ratios of precipitation

\begin{tabular}{|c|c|c|c|c|c|c|}
\hline \multirow[t]{2}{*}{ Month } & \multicolumn{2}{|c|}{$\begin{array}{l}\mathrm{CGCM} 1\left(24.1^{\circ} \mathrm{E},\right. \\
\left.120.0^{\circ} \mathrm{N}\right)\end{array}$} & \multicolumn{2}{|c|}{$\begin{array}{l}\text { GFDL-R15 } \\
\left(24.4^{\circ} \mathrm{E}, 120.0^{\circ} \mathrm{N}\right)\end{array}$} & \multicolumn{2}{|c|}{$\begin{array}{l}\text { HADCM2 } \\
\left(25.0^{\circ} \mathrm{E}, 120.0^{\circ} \mathrm{N}\right)\end{array}$} \\
\hline & $\Delta \mathrm{T}$ & Ratio & $\Delta \mathrm{T}$ & Ratio & $\Delta \mathrm{T}$ & Ratio \\
\hline 1 & 1.11 & 0.82 & 1.66 & 1.00 & 1.46 & 1.40 \\
\hline 2 & 1.42 & 0.69 & 2.51 & 1.19 & 1.40 & 1.18 \\
\hline 3 & 1.42 & 1.06 & 1.35 & 0.89 & 1.05 & 0.76 \\
\hline 4 & 1.17 & 0.97 & 1.29 & 1.01 & 1.15 & 1.15 \\
\hline 5 & 1.85 & 1.54 & 1.69 & 0.99 & 1.35 & 1.24 \\
\hline 6 & 1.52 & 1.08 & 1.59 & 1.34 & 0.97 & 1.14 \\
\hline 7 & 1.26 & 1.31 & 1.41 & 0.92 & 1.01 & 0.86 \\
\hline 8 & 1.29 & 1.10 & 1.04 & 0.82 & 1.26 & 0.88 \\
\hline 9 & 1.35 & 1.12 & 1.75 & 0.98 & 1.24 & 1.18 \\
\hline 10 & 1.07 & 0.86 & 2.13 & 1.06 & 1.27 & 0.84 \\
\hline 11 & 1.24 & 0.89 & 2.39 & 0.86 & 1.78 & 0.50 \\
\hline 12 & 1.66 & 0.90 & 2.52 & 0.89 & 1.35 & 1.18 \\
\hline
\end{tabular}

$\Delta \mathrm{T}$ changes in temperature, Ratio ratios of precipitation

\section{Results}

Compositions of land-use scenarios

Based on the logistics models established by Lin et al. (2007) (Table 1), land-use demands (low development demand and high development demand) and land-use conversion rules (Free and agricultural protection conversions), the CLUE-S model is applied to simulate four land-use scenarios for the period 2000-2020. Figures 2 and 3 show agricultural land, forest, built up and grassland in the land-use scenarios during the simulated period in the upstream and downstream watersheds. In the upstream area, agricultural land area in scenarios I, II, III and IV decreased and was constant after the years 2013, 2011, 2016 and 2013, respectively (Fig. 2). Furthermore, changes in agricultural land in scenarios II and I are similar in area during the simulated period, as are area for change areas in scenarios III and IV during the simulation period (Fig. 2). In the upstream area, forest areas in scenarios III and I are similar during the simulation period, as are the areas in scenarios II and IV (Fig. 2). The built-up area of the upstream watershed increased significantly for all scenarios during the simulated period. The magnitudes of grassland area in scenarios II and I are similar during the simulation period, as are the areas in scenarios III and IV during the simulation period in the upstream area (Fig. 2). Furthermore, the grassland area in scenarios III and IV increased (during 2005 and 2020) and differed to area in scenarios II and I (Fig. 2). In downstream areas, agricultural land area in all scenarios decreased (Fig. 3). Moreover, forest and builtup areas in scenarios III and I are similar in area during the simulation period, as are area in scenarios II and
IV during the simulation period (Fig. 3). During the simulation period, the forest area and built-up area of the downstream watershed in all scenarios decreased and increased, respectively (Fig. 3). Moreover, the magnitudes of the grassland area in all scenarios decreased during the simulation period in the upstream area (Fig. 3).

Hydrological components under land-use scenarios with no climate change

Based on historical weather data (i.e., data from a period with no climate change), streamflows, surface runoffs and groundwater discharges are simulated using the GWLF model and further land-use changes for the period 2000-2020 for both the upstream watershed and the entire watershed. To compare annual variations in hydrological components, the differences in the annual streamflow, annual surface runoff and annual groundwater discharge based the land uses in 1999 (no change) and hydrological components (based on land-use demands and four land-use scenarios for the period 2000-2020) in the upstream watershed and the entire watershed during the simulation period, the annual streamflows, runoff and groundwater discharges are calculated based on simulated monthly streamflows (Figs. 4, 5). Differences in annual streamflow due to land-use change scenarios gradually increased to $0.16 \%$ (scenario I), $0.25 \%$ (scenario II), $0.25 \%$ (scenario III) and $0.25 \%$ (scenario IV) during the simulation period for the upstream area (Fig. 4a). Differences in annual surface runoff due to land-use change scenario increased to $1.11 \%$ (scenario I), $1.47 \%$ (scenario II), $1.47 \%$ (scenario III) and $1.44 \%$ (scenario IV) during the simulation period in the upstream area (Fig. 4b). Moreover, differences in annual groundwater discharge due to land-use change scenario decreased to $0.80 \%$ (scenario I), $0.98 \%$ (scenario II), $0.98 \%$ (scenario III) and $0.94 \%$ (scenario IV) during the simulation period in upstream area (Fig. 4c). For the entire watershed, the differences in annual streamflows between land-use change and no change gradually increase to $0.60 \%$ and $0.50 \%$ for the high and low demands during the simulation period (Fig. 5a). Differences in annual surface runoff between no landuse change and land-use change scenarios increased to 4.00 (high demand) and 3.22\% (low demand) during the simulation period for the entire watershed (Fig. 5b). Furthermore, differences in annual groundwater discharge between no land-use change and landuse change situations decreased to 2.80 (low demand) and $3.50 \%$ (high demand) during the simulation period (Fig. 5c) for the entire watershed. 
Fig. 2 Simulated land-use change of (a) agricultural land, b forest, c built up, d grassland in upstream watershed

Fig. 3 Simulated land-use change of (a) agricultural land, b forest, c built up, d grassland in downstream watershed
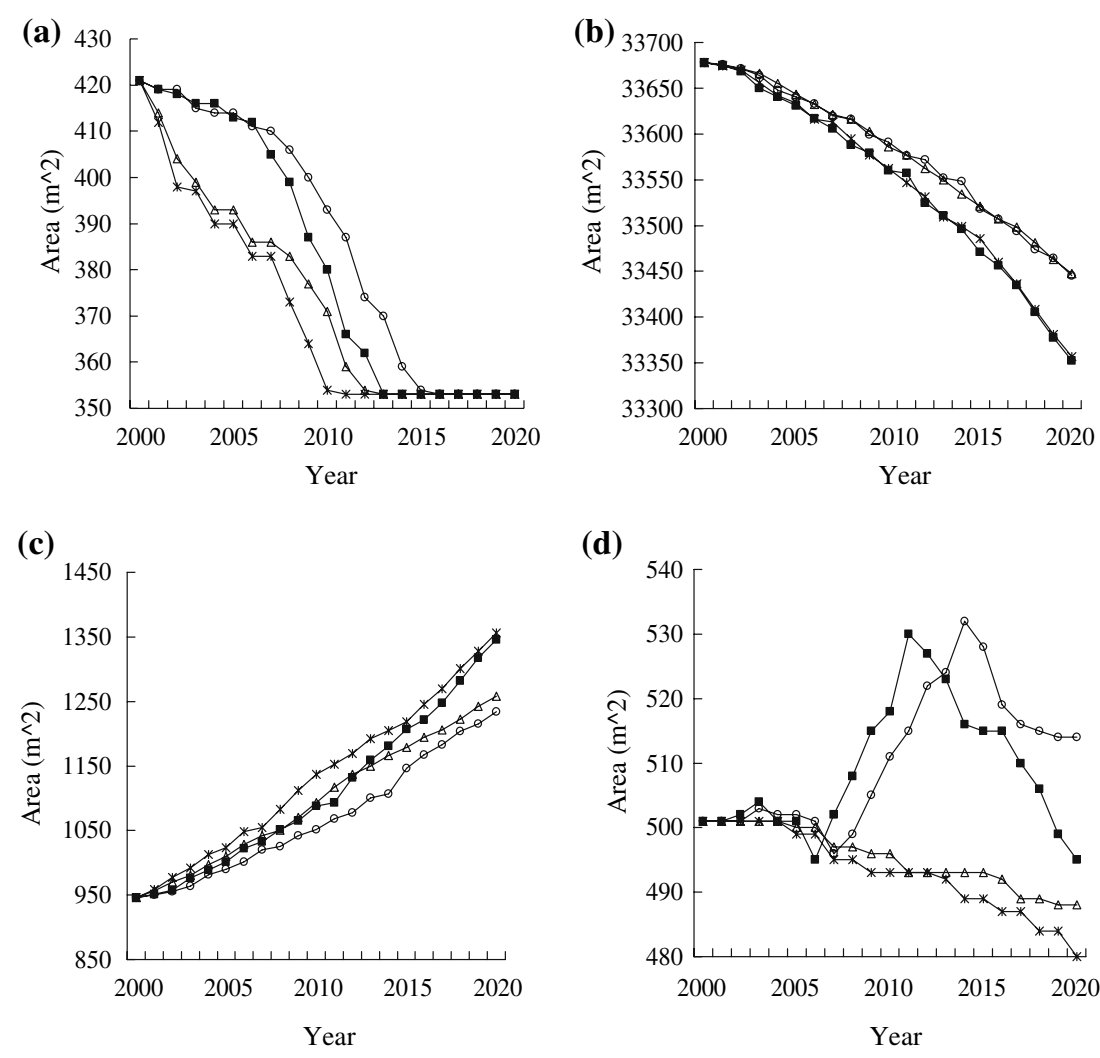

(d)

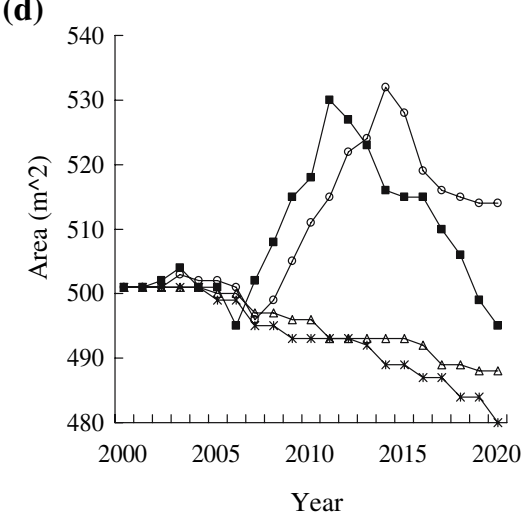

$\triangle$ Scenario I $\quad *$ Scenario II

Scenario III

Scenario IV
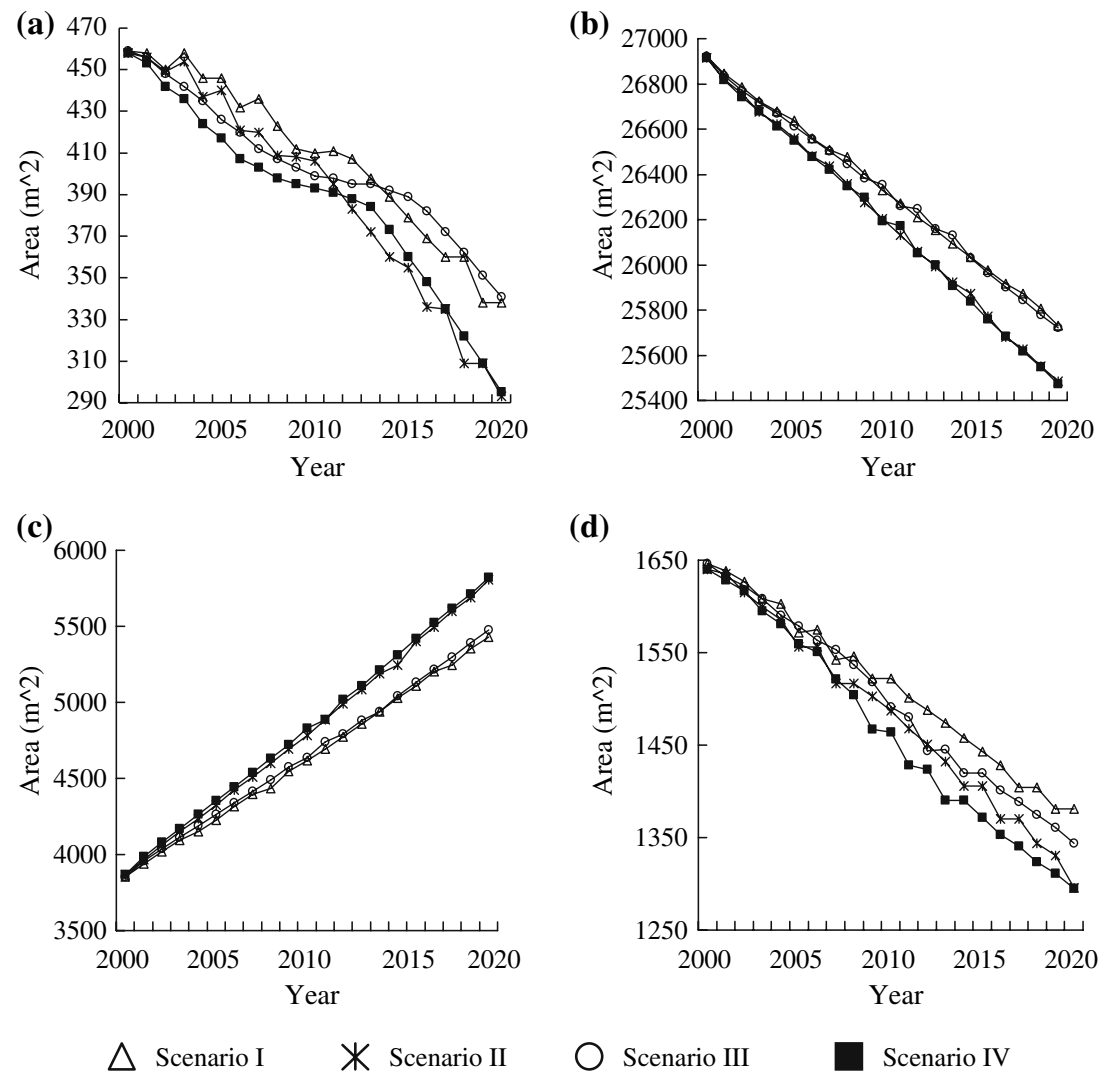

(d)

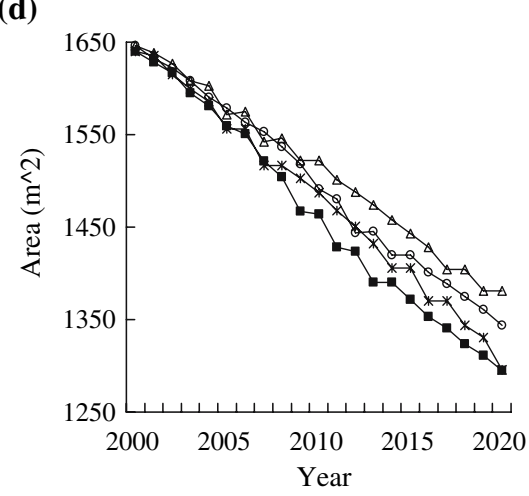

$\bigcirc$ Scenario III $\quad$ Scenario IV 
Hydrological components under land-use scenarios and climate change

Based on climate scenarios of GCM models, streamflows, surface runoff and groundwater discharge is simulated using the GWLF model and simulated 2020 land-use for four land-use scenarios in the upstream watershed and land-use demands in the entire watershed. To compare annual variations in hydrological components, the differences in the annual streamflow, annual surface runoff and annual groundwater discharge based on the 1999 and 2020 land-use scenarios in the upstream watershed and the entire watershed the annual streamflows, runoff and groundwater discharges are calculated based on simulated monthly streamflows (Figs. 6, 7). The differences in annual streamflow between the no land-use change situation and each scenario change decreased from 0.21 to $1.45 \%$ (for CGCM and GFDL) and increased from 1.31 to $1.43 \%$ (for HADCM) for the scenario for the year 2020 in the upstream area under climate change (Fig. 6). Differences in annual surface runoff between the no land-use change situation and each scenario increased from 2.51 to $6.19 \%$ for all land-use scenarios and all climate changes in the upstream area (Fig. 6). Differences in annual groundwater discharge between the no land-use change situation and each scenario decreased from -3.12 to $-6.68 \%$ for all land-use scenarios under all climate change scenarios (CGCM, GFDL and HADCM) in upstream area (Fig. 6). The differences in annual streamflows between the land-use change and no change situations increased from 0.16 to $1.85 \%$ (CGCM and HADCM) and decreased from 0.86 to $0.94 \%$ for two land-use demands by 2020 in the entire watershed (Fig. 7). Differences in annual surface runoff between the land-use change and no change situations increased from 4.70 to $7.54 \%$ (low demand) and 5.47 to $8.29 \%$ (High demand) in 2020 under the climate change scenario (Fig. 7). Differences in annual groundwater discharge between land-use change and
Fig. 4 Cumulative change of (a) streamflow, b runoff, c groundwater discharge in upstream watershed
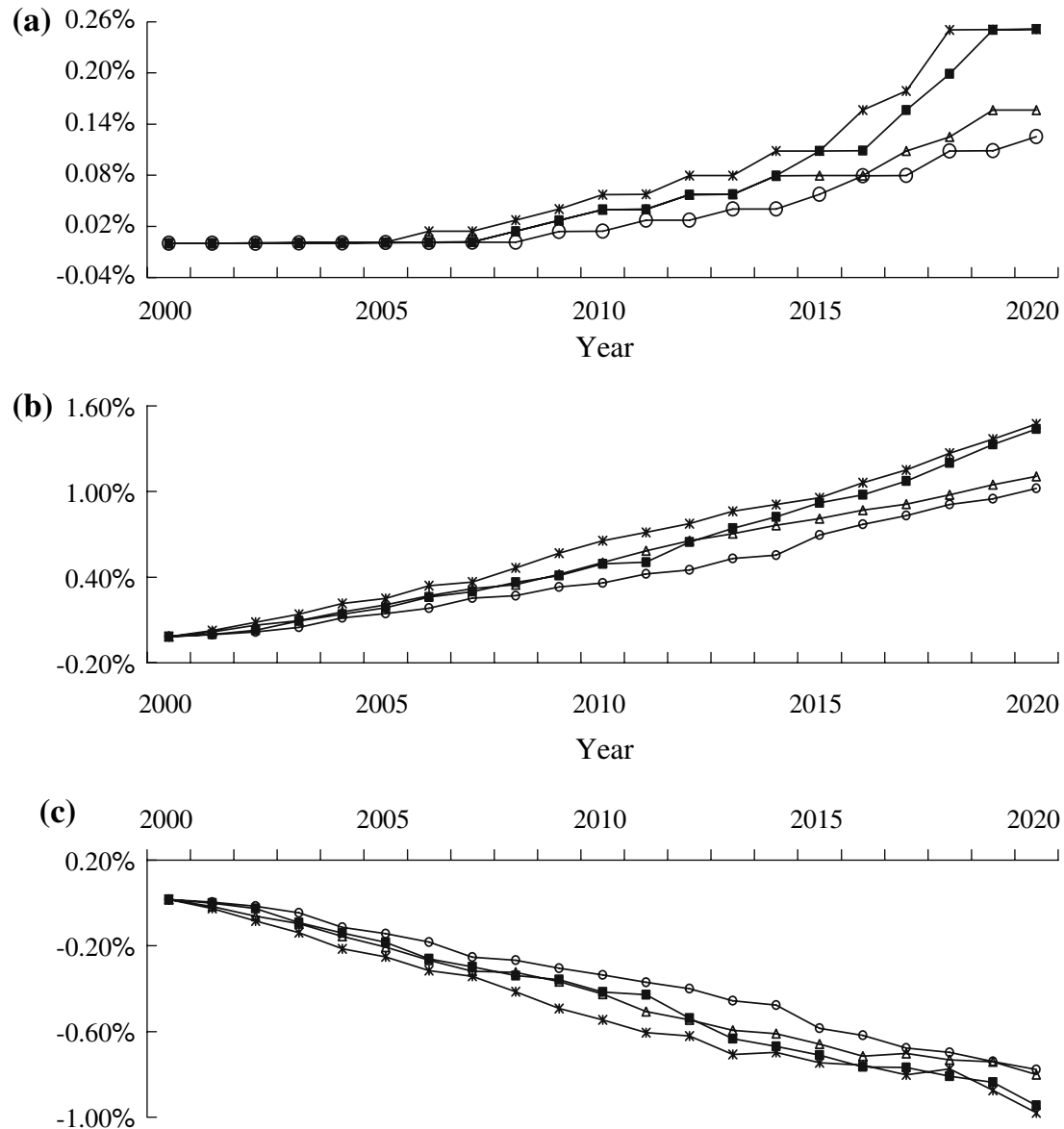

Year

$\triangle$ Scenario I $*$ Scenario II $\bigcirc$ Scenario III $\square$ Scenario IV 
Fig. 5 Cumulative change of (a) streamflow, b runoff, c groundwater discharge in the entire watershed

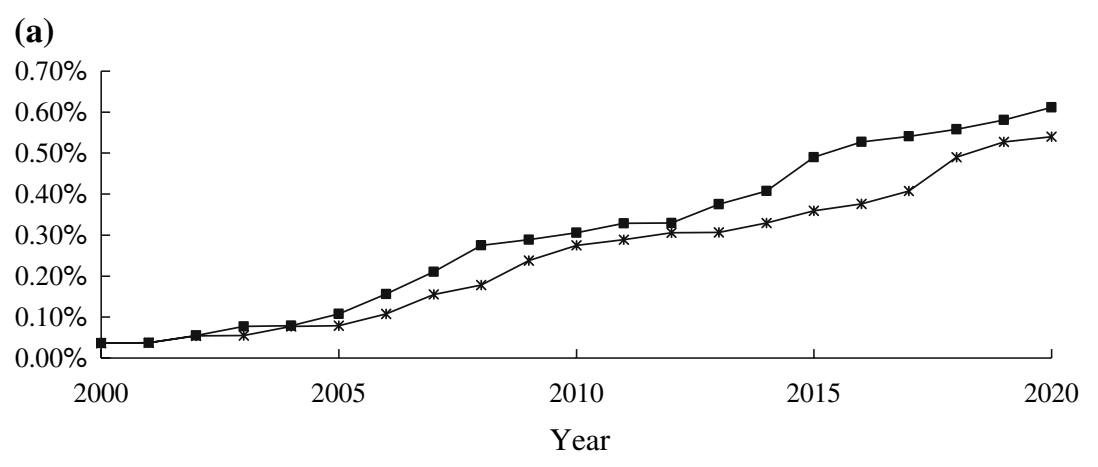

(b)
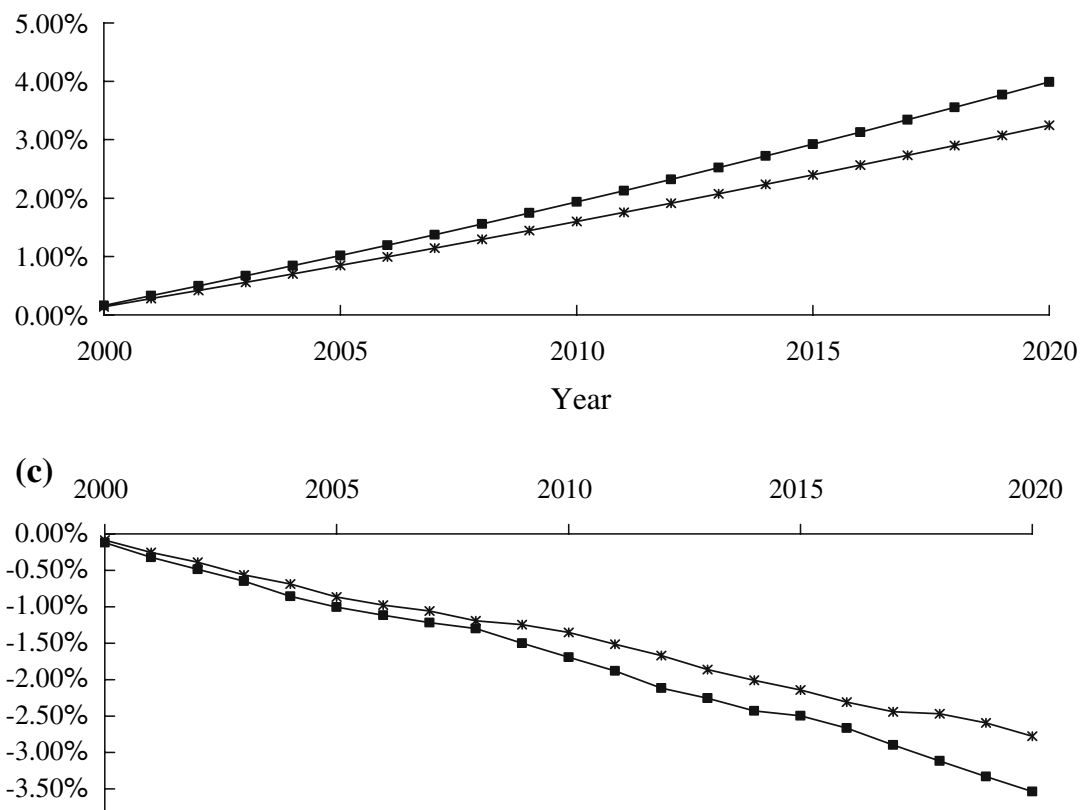

$-4.00 \%$

* Low Demand $\square$ High Demand no change decrease from -5.44 to $-8.69 \%$ (low demand) and from -6.20 to $-9.42 \%$ (high demand) by the year 2020 in the climate change scenario (Fig. 7).

\section{Discussion}

Responses of land-use and climate scenarios on hydrology

Understanding impacts of land use/land cover (LU/ LC) change on the hydrologic cycle is needed for optimal management of natural resources (Scanlon et al. 2005). In this study, if only land-use changes were considered, then future land-use change scenarios had various impacts on the hydrological components (streamflow, surface runoff and groundwater discharge) through time and under various levels of land-use change pressure (various land-use demands). For upstream areas, the impacts on annual streamflow, surface runoff and groundwater discharge of scenario IV were 1.5, 1.3 and 1.17 times greater than those of scenario I. Moreover, various land-use demands and policies influenced future hydrological components in the study watershed, especially in highly developed areas. The influence on hydrological components in the study watershed increased with demand from built-up areas. For the entire watershed, the impacts on annual streamflow, surface runoff and groundwater discharge of the high development demand were 1.20, 1.24 and 1.25 times greater than those from the low development demand. Furthermore, the highest impacts on annual streamflow, surface runoff and groundwater discharge for the entire watershed were 1.50, 2.70 and 3.70 times higher than those for the upstream area. However, surface runoff from urban areas increased 
Fig. 6 Difference in simulated hydrological components between (a) scenario I, b scenario II, c scenario III, d scenario IV and no land use change under climate change in upstream watershed
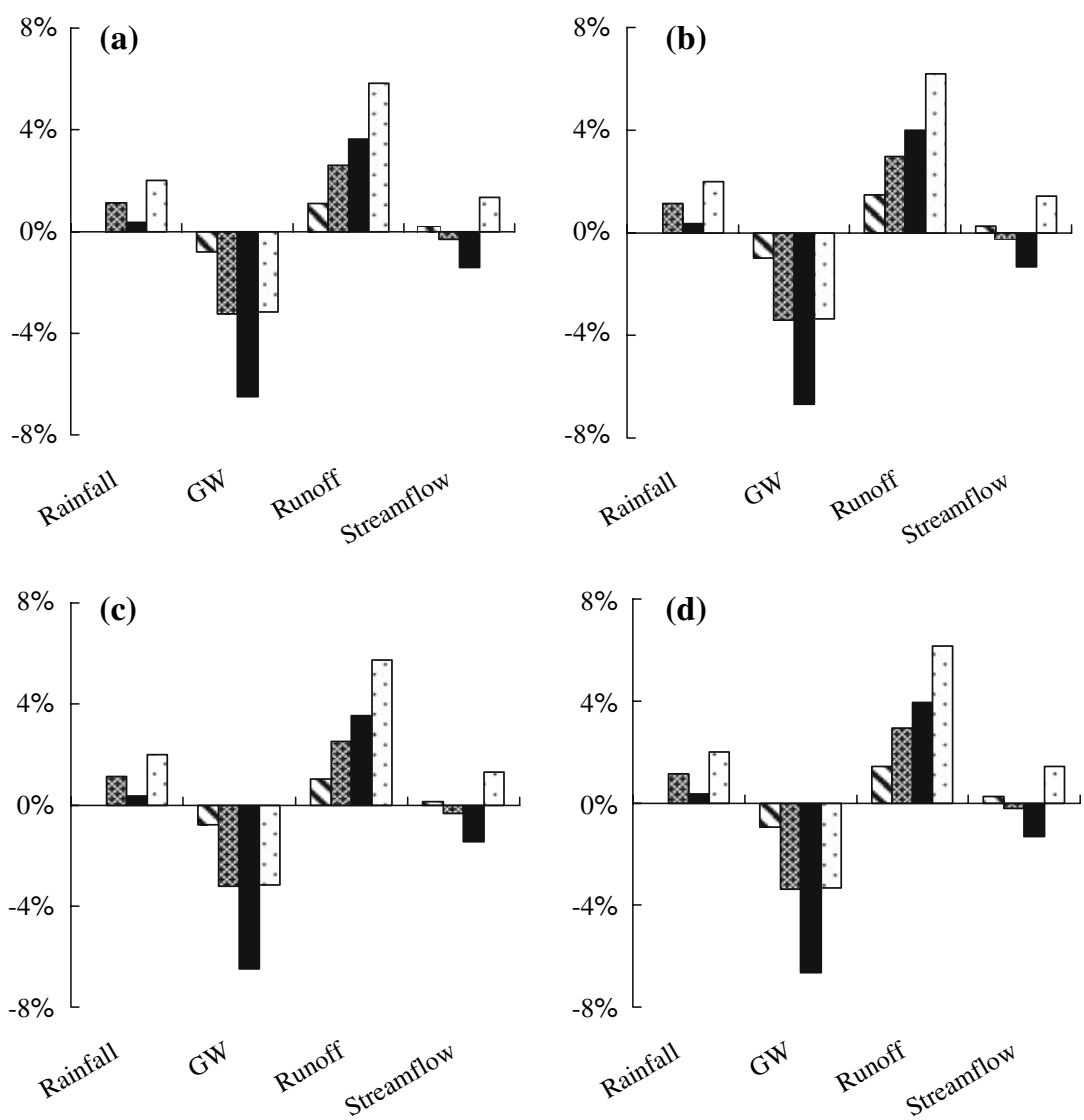

$\mathbf{N}$ Climate $\quad \square$ CFDL $\because \mathrm{HADCM}$ and groundwater discharge decreased as replacement of vegetation through development reduces infiltration.

A global warming could have a significant impact on local and regional climatic regimes, which would have impact upon hydrological and water resources systems (Arnell and Reynard 1996). Changes in climate, either long-term or short-term changes, can alter significantly the hydrological behavior of catchments (Bouraoui et al. 2004). The effects of climate change on river flows depend not only on the extent of change in climatic inputs to the catchment, but also on the characteristics of the catchment itself (Arnell 2003). Comparing the impacts of both land-use and climate changes on hydrology; climate changes impacted the hydrological components much more strongly than land-use changes for all scenarios in the study area, and had a particularly large impact on runoffs and groundwater discharges. However, the increases in precipitation caused by climate change increased annual surface runoff (1.37-2.32 times) more than did the no climate change situation for all land-use change scenarios in all climate change scenarios for the entire watershed in 2020. The impacts of climate changes on annual groundwater discharges were greater (1.71-1.96 times) than those of no climate changes during 2020 for the study watershed in all land-use scenarios. The impacts of climate changes on annual streamflows were slightly greater or less than those of no climate changes in 2020 for the study watershed for all land-use scenarios. These slight and varied differences may be due to the water balances of high changes (increases) of surface runoff and groundwater discharges (decreases) for all land-use scenarios in the study watershed.

Comparing the increase in the ratios of annual surface runoff between the upstream and entire area, the highest increase in the ratios of annual surface runoffs for the entire watershed were higher (1.35-1.87 times) than those in the upstream area for climate changes in 2020. Comparing the decreasing ratios of annual groundwater discharges in both the upstream and the entire areas, the highest decrease ratio of annual groundwater discharges in the entire watershed were higher (1.42-1.84 times) than in the upstream area in the climate change situation in 2020 . The low change in streamflow could be explained by the water balance of 
Fig. 7 Difference in simulated hydrological components between (a) low demand, $\mathbf{b}$ high demand and no land use change under climate change in the entire watershed
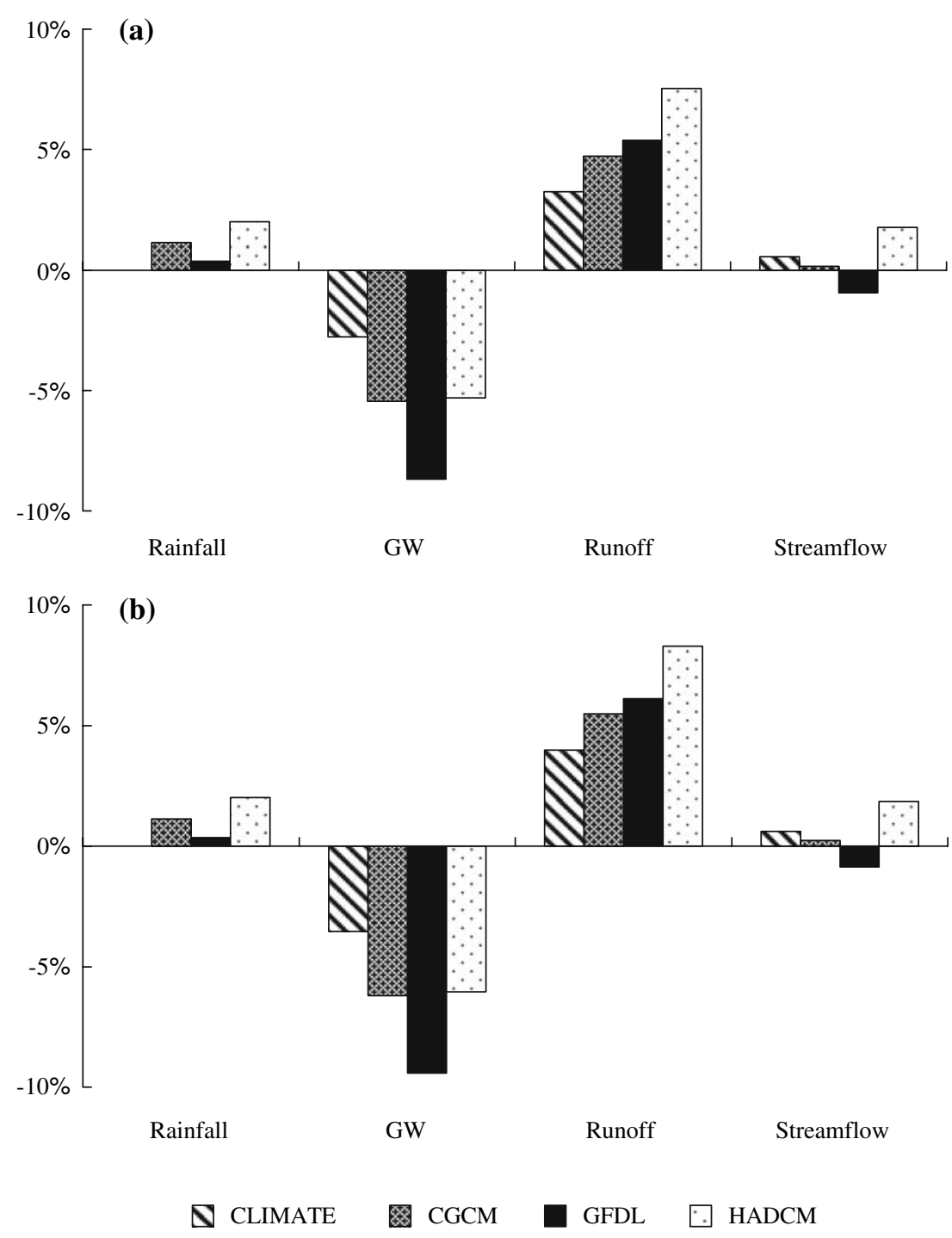

increasing surface runoff and decreasing groundwater discharge in 2020 . However, the impacts by considering both land-use and climate changes were significantly higher than by only considering climate change or land-use change for surface runoff and groundwater discharge. This study did not consider the interactions between land-use change and climate changes. This issue should be also included in further related works.

\section{Conclusion}

This study provided a framework that integrated mathematical models to simulate and assess future land-use and climate change scenarios, as well as their compositions and hydrological components, under various land-use policies in the $\mathrm{Wu}-\mathrm{Tu}$ watershed in Taiwan. In this study, land-use compositions and changes are associated with land-use demands and conversion policies for future watershed planning and management in the study watershed. The variability and magnitudes of future hydrological components were influenced by land-use change scenarios, and particularly runoff and groundwater discharge. The climate changes influenced future surface runoff and groundwater discharge more strongly than land-use changes did in the study watershed. The future landuse and climate change scenarios influenced future land-use compositions and hydrology in both the upstream and downstream watershed, and in particular influenced surface runoff and groundwater discharge in the downstream watershed. The conversion and forest protection policies are particularly effective for the watershed conversion planning given changes in landuse and climate. Future studies should also examine interaction of land-use and climate changes. Moreover, 
alternative land-use and hydrological models should also be applied and compared in future related studies.

Acknowledgments The authors would like to thank the National Science Council of the Republic of China, Taiwan, for financially supporting this research under Contract nos. NSC932621-Z-034-004 and NSC94-2621-Z-002-031. The authors would also like to appreciate Dr. Verburg and the CLUE-S group for providing the CLUE-S model.

\section{References}

Agarwal DK, Silander JA Jr, Gelfand AE, Deward RE, Mickelson JG Jr (2005) Tropical deforestation in Madagascar: analysis using hierarchical, spatially explicit, Bayesian regression models. Ecol Modell 185:105-131

Arnell NW (2003) Relative effects of multi-decadal climatic variability and changes in the mean and variability of climate due to global warming: future streamflows in Britain. J Hydrol 270:195-213

Arnell NW, Reynard NS (1996) The effects of climate change due to global warming on river flows in Great Britain. $\mathbf{J}$ Hydrol 183:397-424

Aspinall R (2004) Modelling land use change with generalized linear models - a multi-model analysis of change between 1860 and 2000 in Gallatin Valley, Montana. J Environ Manage 72:91-103

Bolliger J (2005) Simulating complex landscapes with a generic model: Sensitivity to qualitative and quantitative classifications. Ecol Complexity 2:131-149

Bouraoui F, Grizzetti B, Granlund K, Rekolainen S, Bidodlio G (2004) Impact of climate change on the water cycle and nutrient losses in a Finnish catchment. Clim Change 66:109_ 126

Cheng SJ, Wang RY (2002) An approach for evaluating the hydrological effects of urbanization and its application. Hydrol Process 16:1403-1418

DeFries R, Eshleman KN (2004) Land-use change and hydrologic processes: a major focus for the future. Hydrol Process 18:2183-2186

Dibike YB, Coulibaly P (2005) Hydrologic impact of climate change in the Saguenay watershed: comparison of downscaling methods and hydrologic models. J Hydrol 307:145163

Evans TP, Kelley H (2004) Multi-scale analysis of a household level agent-based model of landcover change. J Environ Manage 72:57-72

Fang S, Gertner GZ, Sun Z, Anderson AA (2005) The impact of interactions in spatial simulation of the dynamics of urban sprawl. Landsc Urban Plan 73:294-306

Fohrer N, Eckhardt K, Haverkamp S, Frede HG (1999) Effects of land use changes on the water balance of a rural watershed in a peripheral region (in German). J Rural Eng Dev 40:202-206

Fohrer N, Moller D, Steiner N (2002) An interdisciplinary modelling approach to evaluate the effects of land use change. Phys Chem Earth 27:655-662

Fohrer N, Haverkamp S, Frede HG (2005) Assessment of the effects of land use patterns on hydrologic landscape functions: development of sustainable land use concepts for low mountain range areas. Hydrol Process 19:659-672

Haith DA, Shoemaker IL (1987) Generalized watershed loading functions for stream flow nutrients. Water Resour Bull 107:121-137
Hamon WR (1961) Estimating potential evapotranspiration. Proceedings of the American Society of Civil Engineering. J Hydraul Div 87:107-120

Hietel E, Waldhardt R, Otte A (2004) Analysing land-cover changes in relation to environmental variables in Hesse, Germany. Landsc Ecol 19:473-489

Howarth RW, Fruci JR, Sherman D (1991) Input of sediment and carbon to an estuarine ecosystem: influence of land use. Ecol Appl 1:27-39

Lin YP, Hong NM, Wu PJ, Wu CF, Verburg PH (2007) Impacts of land use change scenarios on hydrology and land use pattern in the $\mathrm{Wu}-\mathrm{Tu}$ watershed in Northern Taiwan. Landsc Urban Plan (in press)

Manson SM (2005) Agent-based modeling and genetic programming for modeling land change in the Southern Yucatán peninsular region of Mexico. Agric Ecosyst Environ 111:4762

Matondo JI, Peter G, Msibi KM (2004) Evaluation of the impact of climate change on hydrology and water resources in Swaziland: part I. Phys Chem Earth 29:15-18

Prudhomme C, Jakob D, Svensson C (2003) Uncertainty and climate change impact on the flood regime of small UK catchments. J Hydrol 227:1-23

Ringius L, Downing TE, Hulme M, Waughray D, Selrod R (1996) Climate change in Africa: issues and challenges in agriculture and water for sustainable development. CICERO, report 8. University of Oslo, Norway, p 151

Scanlon BR, Reedy RC, Stonestrom DA, Prudic DE, Dennehy KF (2005) Impact of land use and land cover change on groundwater recharge and quality in the southwestern US. Glob Change Biol 11:1577-1593

Singh VP, Woolhiser DA (2002) Mathematical modeling of watershed hydrology. J Hydrol Eng 7:270-292

Syphard AD, Clarke KC, Franklin J (2005) Using a cellular automaton model to forecast the effects of urban growth on habitat pattern in southern California. Ecol Complexity 2:185-203

Thomson AM, Brown RA, Rosenberg NJ, Srinivasan R, Izaurralde $\mathrm{C}$ (2005) Climate change impacts for the conterminous USA: an integrated assessment. Clim Change 69:67-88

Tung CP (2001) Climate change impacts on water resources of the Tesngwen Creek watershed in Taiwan. J Am Water Resour Assoc 37:167-176

Tung CP, Lee TY, Yang YC (2005) Modelling climate-change impacts on stream temperature of Formosan landlocked salmon habitat. Hydrol Process 20:1629-1649

Turner BL, Moss RH, Skole DL (1993) Relating land use and global land cover change, IGBP report no. 24, HDP report no. 5. International geosphere-biosphere programme, Stockholm, p 132

US country studies program (1995) ftp://www.ncardata.ucar.edu/ pub. Cited in NCAR ftp site

Verburg PH, Veldkamp A (2004) Projecting land use transitions at forest fringes in the Philippines at two spatial scales. Landsc Ecol 19:77-98

Verburg PH, Soepboer W, Veldkamp A, Limpiada R, Espaldon V (2002) Modeling the spatial dynamics of regional land use: the CLUE-S model. Environ Manage 30(3):391-405

Wang X, Yu S, Huang GH (2004) Land allocation based on integrated GIS-optimization modeling at a watershed level. Landsc Urban Plan 66:61-74

Weaver K, Perera AH (2004) Modelling land cover transitions: a solution to the problem of spatial dependence in data. Landsc Ecol 19:273-289 